\title{
EDITORIAL
}

\section{The JBPML as a bridge between the investigative scientists and the medical profession}

Adagmar Andriolo

In this first issue of the Brazilian Journal of Pathology and Laboratory Medicine 2014, as usual, we find several articles of interest to our areas of expertise, all of them showing a strong relation between the diagnostic tools currently available and the quality of health care. Adequate knowledge of the capabilities and limitations of laboratory arsenal recently made available to medical practice is of fundamental importance for their use in a rational way. This feature strengthens the position of our Journal as a bridge between the various medical areas, approaching, more and more the clinic and the laboratory.

Two of the articles "Determination of serum lithium: between atomic emission and absorption spectrometry methods"(4) and "Performance evaluation of the Sysmex ${ }^{\circledR}$ XE-2100D automated hematology analyzer"(7) primarily discuss technical aspects, evaluating methodology and equipment without however, neglecting the clinical implication that these exams have. The dosage of lithium for the purpose of therapeutic drug monitoring is crucial to custom fit the optimal dose and as a marker of treatment adherence. A critical evaluation of the performance of an automated hematology analyzer, aimed at establishing the $\mathrm{CBC}$, one of the most used tests in routine medical practice is always relevant task, especially to contribute to the harmonization of results from new and different equipment.

Two other studies "Study on the stability of internal quality control sera for immunodiagnostic tests" (3) and "Homogeneity study of the internal quality control sera for immunodiagnosis of HIV/AIDS" ${ }^{(2)}$ focus on aspects related to different resources for quality control of laboratory procedures. Levels of excellence in quality, despite every effort, are not easy to obtain and mainly kept in complex routines. Among other arrangements, use of reference materials reliable over time is required. Knowing the quality of the components responsible for quality assurance itself is a basic requirement in good laboratory practices.

Reflecting the importance of the subject, neoplastic processes are present in five other studies of this issue "The relationship between serum levels of CA 125 and degree of differentiation in ovarian neoplasm"(1), "Renal tumors: evaluation of prognostic factors in 98 cases from reference hospital in Porto Alegre, Brazil"(5), "Clinical and histopathological evidence of oral squamous cell carcinoma in young patients. Systematized review"(8), "Thalidomide promotes leukocytosis in mice inoculated with 4T1 mammary carcinoma"(9), and "Association between human papillomavirus (HPV) and the oral squamous cell carcinoma: a systematic review”(6), including two systematic reviews. In addition to concern with early diagnosis, much has been invested in identifying conditions of risk, carcinogenic factors, biomarkers that allow classifying neoplastic processes regarding aggressiveness and consequently the patient's prognosis and assessment of potential responsiveness to certain therapeutic approaches.

The last item to be mentioned is a case report, "Large oral focal mucinosis: a case report" ${ }^{(10)}$, which offers the opportunity to be revised some differential diagnoses of oral lesions.

Have a good reading.

Associate Professor of Department of Medicine at Medical School at Universidade Federal de São Paulo (Unifesp) 


\section{REFERENCES}

1. CAMBRUZZI, E. et al. The relationship between serum levels of CA 125 and degree of differentiation in ovarian neoplasm.J Bras Patol Med Lab, v. 49, n. 1, p. 20, 2014.

2. CASTEJON, M. J. et al. Homogeneity study of the internal quality control sera for immunodiagnosis of HIV/AIDS.J Bras Patol Med Lab, v. 49, n. 1, p. 46, 2014.

3. CASTEJON, M. J. et al. Study on the stability of internal quality control sera for HIV/AIDS immunodiagnostic tests. J Bras Patol Med Lab, v. 49, n. 1, p. 36, 2014.

4. ESPÍRITO SANTO, C. E.; CARVALHO, T. M. J. P. Determination of serum lithium: comparison between atomic emission and absorption spectrometry methods.J Bras Patol Med Lab, v. 49, n. 1, p. 12, 2014.

5. FREITAS, A. M. S. et al. Renal tumors: evaluation of prognostic factors in 98 cases from reference hospital in Porto Alegre, Brazil. J Bras Patol Med Lab, v. 49, n. 1, p. 57, 2014.

6. LIMA, M. A. P. et al. Association between human papillomavirus (HPV) and the oral squamous cell carcinoma: a systematic review. J Bras Patol Med Lab, v. 49, n. 1, p. 75, 2014.

7. MACIEL, T. E. S. et al. Performance evaluation of the Sysmex ${ }^{\circledR}$ XE-2100D automated hematology analyzer.J Bras Patol Med Lab, v. 49, n. 1, p. 26, 2014.

8. MESQUITA, J. A. et al. Clinical and histopatological evidence of oral squamous cell carcinoma in young patients: systematized review.J Bras Patol Med Lab, v. 49, n. 1, p. 67, 2014.

9. REIS, D. C. et al. Thalidomide promotes leukocytosis in mice inoculated with $4 \mathrm{T1}$ mammary carcinoma.J Bras Patol Med Lab, v. 49, n. 1, p. 64, 2014.

10. SILVA, K. R. et al. Large oral focal mucinosis: a case report. J Bras Patol Med Lab, v. 49, n. 1, p. 75, 2014. 